\title{
Elements of Nature as the Object of Escapism in Maya Angelou's “Woman Work”
}

\author{
Rr. Arielia Yustisiana \\ lia.6606@gmail.com \\ English Department, Universitas Katolik Widya Mandala Madiun
}

\begin{abstract}
The research aimed to discuss the elements of nature in the poem entitled "Woman Work" written by Maya Angelou. The speaker of the poem used nature as the object of escapism. The research used some theories to meet the topic of discussion. The basic theories of the research were symbol, imagery and figures of speech. They were two figures of speech as the poetic devices in the poem: personification and apostrophe. They were two supporting theories that dealt with the topic, i.e. nature and escapism. There were two approaches that were used: structural and formalistic approaches. Library research is the technique of collecting data. The finding of the research was that the speaker of the poem endowed the elements of nature (which are non-living objects) with human qualities in an attempt to feel less lonely. In the absence of human company, it was the sun, the rain, the snow, dewdrops, the wind, the sky, mountains, oceans, leaves, stones, "star shine" and "moon glow" that were her friends. "Woman Work" was a very domestic poem depicting the typical routine life of a woman who performed her daily chores effectively and then yearned for a fantastic break amidst the elements of nature to give her strength and comfort.
\end{abstract}

Keywords: nature, escapism, symbol, imagery, personification

\section{Introduction}

Women are always the most discussed topics in all the countries of the world and in the whole history of the universe. Some groups talk against women and some other fight for their rights. Even now, in few regions of the word, women are living in a very disgusting condition; at the same time other women are enjoying the beauty, adornments and luxury of the world with equal status as men.

There are many literary works that depict what women have done dealing with the equality with men and fought for in the family and society; how they survive in their sense of the inferiority; and how they can solve their obstacles with the oppressors when they become the oppressed. Literature becomes a means of expressing those things dealing with the experiences of women in living their life.

Poetry is a form of literary art that uses a beautiful and unique language. A poem is one piece of a poet's literary works in verse form. According to Annas in How the Poetry Works,

A poem is concerned with emotion, it is emotion shaped, controlled, and contained in form. A poem often says something significant; it attempts to achieve beauty. Of course, what is significant and beautiful is open to discussion and may change with time and place (1996: 181).

Reading a poem needs a particular emotion to understand its deep meaning because it is 
concerned with ideas and insights. Everyone has their own understanding in order to interprete the meaning of a poem. Readers may have found from their reading that they can often enjoy a poem without fully understanding its meaning. Before readers say why they like a poem, it is necessary to understand its meaning well.

"Woman Work" is a simple poem written by an American Poetess, Maya Angelou. Angelou's identity as an African American, a woman, and an African American woman influences her poetry much. This is true in all the poems included in And Still I Rise (republished in 2001 as Still I Rise). The theme of self-identity in "Woman Work" is especially interesting because the poem allows two related but different interpretations.

This research, however, focuses on the elements of nature that are addressed by the speaker in Maya Angelou's "Woman Work". The elements of nature have implicit meanings and they can direct to the speaker's escape to the world that she wishes. The character sketch of a woman drawn in this poem is always busy in her household work. All the day she works like a machine in house. She becomes tired and wants to give herself relief from her responsibilities because she is fed up with her monotonous homely life. Then, she desires to go in the lap of nature. The speaker expresses her boredom and wants to release it through nature. She asks nature to come and give her joy and change her dull and boring life into a changing life. The speaker expresses her ambition to find refuge in the object of nature.

There are some main components of nature in the poem, such as sun, rain, and snow drops. The speaker loves the sunshine and the rain that could purify her. She wants to bury herself under the snowflakes. Nature would help her recover her loss of energy. She considers nature as her only well-wisher. Nature becomes the object of the speaker's escapism because she is so tired of her daily courses. Maya Angelou provides the reader with details of her speaker's workaday world, a world in which every day is like the last day, and relief is found only in communing with nature. Angelou's masterful manipulation of words presents two possible scenarios: the speaker is a slave or she is representative of any woman whose daily life is dedicated to caring for others. This research, however, focuses on the elements of nature that become the object of escapism.

The following theories are relevant to meet the aims. The first is the theory of symbol, imagery, personification, and apostrophe as the basic theories dealing with poetic device. The second is the theory of nature and escapism.

\section{Symbol}

Symbol is something that refers to something else. Finding out a symbol deals with figurative meaning because it means beyond its real meaning or literal meaning. A symbol is something that is literally itself (for example a shiny, patent leather shoe) and at the same time represents or suggests something else (childish innocence or purity). In other words, a symbol is a literal object or thing that suggests another level of meaning; a symbol may suggest a person, an abstraction, or an idea. A symbol is basically a kind of image, differing from other images in the use to which it is put (Kenney, 2005: 75). A symbol in a story may, in fact, harbor multiple levels of meaning.

In addition, Kenney also claims "it is this attempt that the symbol, while evoking a concrete, objective reality, also suggests an additional 'level of meaning' beyond that reality" (1988: 75). The other definition of symbol is stated by Kennedy in his book entitled Literature: An Introduction to Fiction, Poetry, and Drama: "A symbol is a thing that suggests more than its literal meaning. Symbols generally do not 'stand for' any one meaning, nor for anything absolutely definite" (2010: 113).

\section{Figures of Speech}

Figure of speech is an expression in which the words are used in a nonliteral sense to present a figure, picture or image. There are some poetic devices when we want to analyze an English poem more deeply. In figurative language we employ words in such a way that they differ somewhat from their ordinary 
signification in commonplace speech and convey our meaning in a more vivid and impressive manner than when we use them in their every-day sense. Figures of speech make speech more effective. They beautify and emphasize speech. Figures of speech are organized into different categories such as metaphor, similes, irony and are used as a poetic device.

Figures of speech use word association to convey emotion and mood often in a nonliteral sense. Figures of speech add adornment, beauty, colors, elegant variation, embellishment, embroidery, emphasis, exclamation, flourish, floweriness, irony, lushness and add luxuriance to the English language and often used by famous poets as a poetic device. and Voice,

According to Cheuse in Literature Craft

figures of speech are a technique of using language to describe one thing in terms of another, often comparing two unlike objects, such as the sun and the face of the beloved, to condense and heighten the effect of language, particularly the effect of imagery or symbolism in a poem" (2010: G-6).

It means that figures of speech are words or phrases that have connotative meaning. The figures of speech itself can be described in terms of technique of using language which is aimed to either strenghten the effect of symbolism and imagery or explain a concept.

It is not easy, though, to understand expressions using figures of speech. It is because expressions have figurative meanings and each expression may have more than one interpretations. Figures of speech are commonly used when a speaker or writer wants to say something in different ways. Holman states as follows:

Figure of speech is two of major kinds: rhetorical figures, which are departures from customary or standard uses of language to achieve special effects without a change in the radical meaning of the words; and TROPES, in which basic changes in the meaning of words occur (2006: 203).

Furthermore, figures of speech or rhetorical figure is in the form of a single word or phrase. It can be a special repetition, arrangement or omission of words with literal meaning, or a phrase with a specialized meaning based on the literal meaning of the words. There are some kinds of figures of speech. They are simile, metaphor, hyperbole, oxymoron, metonymy, personification, apostrophe, and synecdoche.

\section{Personification}

Personification is a figure of speech in which a thing, an idea or an animal is given human attributes. The non-human objects are portrayed in such a way that we feel they have the ability to act like human beings. For example, when we say "the sky weeps" we are giving the sky the ability to cry, which is a human quality. Thus, we can say that the sky has been personified in the given sentence.

As a literary device, personification is the projection of characteristics that normally belong only to humans onto inanimate objects, animals, deities, or forces of nature. These characteristics can include verbs of actions that only humans do or adjectives that describe a human condition. The characteristics can also be emotions, feelings, or motives given to objects incapable of thought. For example, if someone said, "the trees whispered their discontent," this would personify the trees both as able to whisper and of feeling unhappy.

According to Baldick, personification is a figure of speech by which animals, abstract ideas, or inanimate things are referred to as if they were human (1991: 166). To understand personification better, consider the following example (taken from L. M. Montgomery's "The Green Gables Letters"):

"I hied me away to the woods-away back into the sun-washed alleys carpeted with fallen gold and glades where the moss is green and vivid yet. The woods are getting ready to sleep-they are not yet asleep but they are disrobing and are 
having all sorts of little bed-time conferences and whisperings and goodnights."

The lack of activity in the forest has beautifully personified as the forest getting ready to sleep, busy in bed-time chatting and wishing good-nights, all of which are human customs.

Furthermore, Barnet states that personification is a kind of figurative language in which an inanimate object, animal or other nonhuman is given human traits (2005: 1541).

But Time did beckon to the flowers, and they

By noon most cunningly did steal away.

(Herbert)

Herbert attributes a human gesture to time and shrewdness to flowers. Of all figures, personification most surely gives to airy nothings a local habitation and a name.

\section{Apostrophe}

Apostrophe is addressing someone that is absent or dead or something non-human as if that person or thing is present and alive, can reply to what is being said. It occurs when a speaker breaks off from addressing the audience (e.g. in a play) and directs speech to a $3^{\text {rd }}$ party such as an opposing litigant or some other individual, sometimes absent from the scene. Often the addressee is a personified abstract quality or inanimate object. In dramatic works and poetry written in or translated into English, such a figure of speech is often introduced by the vocative exclamation "O". Poets may apostrophize a beloved, the Muse, God, love, time, or any other entity that cannot respond in reality.

According to Baldick, apostrophe is a rhetorical figure in which the speaker addresses a dead or absent person, or an abstraction or inanimate object (1990: 15). In literature, apostrophe is a figure of speech sometimes represented by exclamation " 0 ". A writer or a speaker, using an apostrophe, detaches himself from the reality and addresses an imaginary character in his speech.
Moreover, as a form of direct address to an inanimate object, apostrophes serve to further poetic imagery and often emphasize the emotional weight of objects in our everyday world. Greenblatt (2006: 429) gives an example of apostrophe derived from John Donne's poem entitled "The Sun Rising"
"Busy old fool, unruly Sun,
Why dost thou thus,
Through windows, and through curtains, call on us?
Must to thy motions lovers' seasons run? Saucy pedantic wretch,"

The poet addresses the sun in an informal and colloquial way as if it were a real human being. He asks the Sun in a rude way why the Sun appeared and spoiled the good time he was having with his beloved.

\section{Imagery}

Imagery is language that evokes sensory images. Baldick states that

Imagery is a rather vague critical term
covering those uses of language in a
literary work that evoke sense-
impressions by literal or figurative
reference to perceptible or concrete
objects, scenes, actions, or states, as
distinct from the language of abstract
argument or exposition (1990: 160).

The word 'imagery' is derived from the word 'image' that means a pictorial likeness, literal or figurative, that illustrates idea, object, or action by appealing to the senses. An image is a concrete representation of a sensory experience or object. A literal image refers to something that can be seen, felt, touched, heard, or smelled: an orange, a river, a blue bird flying across the sky. These kinds of images may also be called sensory details-descriptive details that evoke a response from the sense. Literal images are often infused with meanings that go beyond their literal meaning; in some works lines of imagery-or patterns of repeated images-may be identified. Imagery is not decoration; rather, it is integral to a story's meaning in a poem or other literary works. 
In addition, Kennedy in his famous literary book entitled Literature: $A n$ Introduction to Fiction, Poetry, Drama and Writing states that the term image suggests a thing seen, when speaking of images in poetry, we generally mean a word or sequences of words that refer to any sensory experience (2010: 1916). An image may occur in a single word, a phrase, a sentence, a stanza or an entire poem. To speak of the imagery of a poem-all its images taken together-is often more useful than to speak of separate images.

Indeed, some literary critics look for much of the meaning of a poem in its imagery, wherein they expect to see the mind of the poet more truly revealed than in whatever the poet explicitly claims to believe. Images are powerful things. A poem, however, must build its pictures from words-no mean feat. By taking note of its imagery, and watching how the nature of those images evolves from start to finish, the readers can go a long way toward a better understanding of the poem.

\section{Nature}

Nature, in the broadest sense, is the natural, physical, or material world or universe. "Nature" can refer to the phenomena of the physical world, and also to life in general. The study of nature is a large part of science. Although humans are part of nature, human activity is often understood as a separate category from other natural phenomena. According to Rothenberg,

The word nature is derived from the Latin word natura, or "essential qualities, innate disposition", and in ancient times, literally meant "birth". Natura is a Latin translation of the Greek word physis, which originally related to the intrinsic characteristics that plants, animals, and other features of the world develop of their own accord (2011: 23).

The concept of nature as a whole, the physical universe, is one of several expansions of the original notion; it began with certain core applications of the word physis by preSocratic philosophers, and has steadily gained currency ever since. This usage continued during the advent of modern scientific method in the last several centuries.

Within the various uses of the word today, "nature" often refers to geology and wildlife. Nature can refer to the general realm of living plants and animals, and in some cases to the processes associated with inanimate objects-the way that particular types of things exist and change of their own accord, such as the weather and geology of the Earth.

\section{Escapism}

Escapism is the avoidance of unpleasant, boring, arduous, scary, or banal aspects of daily life. It can also be used as a term to define the actions people take to help relieve persisting feelings of depression or general sadness. Escapism is the tendency to seek, or the practice of seeking, distraction from what normally has to be endured. However, many challenge the idea that escapism is fundamentally and exclusively negative.

Industries have sprung up to foster a growing tendency of people to remove themselves from the rigors of daily lifespecially into the digital world. Many activities that are normal parts of a healthy existence (e.g. eating, sleeping, exercise, sexual activity) can also become avenues of escapism when taken to extremes or out of proper context; and as a result the word "escapism" often carries a negative connotation, suggesting that escapists are unhappy, with an inability or unwillingness to connect meaningfully with the world and to take necessary action.

C.S Lewis (in Pratchett, 2012: 276) was fond of humorously remarking that the usual enemies of escape were jailers; and considered that used in moderation escapism could serve both to refresh and to expand the imaginative powers. Similarly, J.R.R Tolkien (in Pratchett, 2012: 286) argued of escapism in fantasy literature as the creative expression of reality within a secondary (imaginative) world, (but also emphasized that they required an element of horror in them. Pratchett (2012: 329) considered that the $20^{\text {th }}$ century had seen the development over time of a more positive view of escapist literature. 


\section{Approaches}

Two approaches are used to support the analysis. The approaches intended to include structural approach and formalist criticism. Structural approach is applied in this research because this kind of approach is very effective for analyzing a poem which has some poetic meaning of the words.

Structural approach concentrates on each constituent of the construction. By understanding the meaning of the words, the truth can be discovered. D'haen states that structural approach is producing relevant results by looking in places where one would not look without being urged by sturdy model (2014: 143). In other words, the structural approach is used to get the mastery over the structures. It concentrates on each word to get the detailed meaning.

Formalist criticism regards literature as a unique form of human's knowledge that needs to be examined in its own terms. The natural, sensible starting point is the interpretation and analysis of the works of literature themselves. To explore the intense relationship within a poem is done by close reading, a careful step-by-step analysis and explication of a text. The formalist criticism which is now called as the new criticism or formalistic approach is defined by Guerin as the assumption that a given literary experience takes a shape proper to itself, or at the least that the shape and the experience are functions of each other (2005: 83). It means that the formalist criticism is concerned primarily with the work itself. The form and content cannot be meaningfully separated since the various stylistic elements of literary work influence each other.

The most suitable method of research used is descriptive method. Punch explains that descriptive method is setting out to collect, organize and summarize information about the matter being studied (2000: 38). Hence, this method is aimed to describe the elements of nature as the object of escapism in the poem "Woman Work" written by Maya Angelou.
The primary data that are used in the research are lines that describe elements of nature and the implicit meaning hidden in each symbol. Therefore, the most suitable method of collecting the data is the library research. George states that library research involves identifying and locating sources that provide factual information or personal/expert opinion on a research question; necessary component of every other research method at some point (2008: 6). It means that some materials in the form of printed media are needed in order to support the analysis. Moreover, the data are also collected from some literary sites in the internet to support the analysis.

\section{"Woman Work"}

"Woman Work" by Maya Angelou is about a woman's chores and jobs throughout the day. The first stanza begins with a list of chores which is written in a fast pace and overwhelming sense of busyness and stress. It seems that the speaker cannot even take a rest for a moment because of her responsibility for finishing her chores. It also shows that the speaker and her family are poor and do not own much. While the second, third, fourth and fifth stanzas slow down to show a resting period in the woman's day. The woman feels that nature is important to her because it is the only thing in her life that does not add any stress and is an outlet for the busy day.

\section{Woman Work}

I've got the children to tend

The clothes to mend

The floor to mop

The food to shop

Then the chicken to fry

The baby to dry

I got company to feed

The garden to weed

I've got shirts to press

The tots to dress

The cane to be cut

I gotta clean up this hut

Then see about the sick

And the cotton to pick.

Shine on me, sunshine

Rain on me, rain 
Fall softly, dewdrops

And cool my brow again.

Storm, blow me from here

With your fiercest wind

Let me float across the sky

'Til I can rest again.

Fall gently, snowflakes

Cover me with white

Cold icy kisses and

Let me rest tonight.

Sun, rain, curving sky

Mountain, oceans, leaf and stone

Star shine, moon glow

You're all that I can call my own.

The setting of the poem is the South. The first clue to the setting is "the chicken to fry." Fried chicken is a popular dish more common in the South. The next clue to the setting is "the cane to be cut." Cane refers to sugar cane which can only be grown in hot climates like the southern United States. The last clue is "the cotton to pick." Similar to sugar cane, cotton is only found in warmer climates.

Moreover, the research focuses on the woman who wants to try to escape from her restless routine chores. The sense of escapism leads to the nature. The speaker feels that the elements of nature that are able to heal her tiredness, boredom of routine work and loneliness.

\section{The Elements of Nature as the Object of Escapism in Maya Angelou's "Woman Work"}

Regarding with the tone of the poem, it is very unique because the speaker feels tension and depression in the first stanza. She speaks without paces that are nearly like she is in hurry and regardless her tiredness, she keeps doing her responsibility to finish all she has to do. Consider the following stanza:

I've got the children to tend

The clothes to mend

The floor to mop

The food to shop

Then the chicken to fry

The baby to dry
I got company to feed

The garden to weed

I've got shirts to press

The tots to dress

The cane to be cut

I gotta clean up this hut

Then see about the sick

And the cotton to pick.

There are no commas or even full stops in every line of the stanza, except the last line of the stanza showing that the speaker has just finished her chores. The woman is given a list of chores to do which tire her out and create more stress in her life. In poetic fashion, the lengthy verse rhymes all the way through, in a general AABB fashion, creating a fast-paced rhythm likely designed to mirror the fast pace of the woman's life. From the content of the list, we can infer that she is a mother, housekeeper, cook, hostess, gardener, nurse, and slave as well, working in fields to harvest cotton and sugarcane, suggesting that the setting of the poem is in the United States of America, or in British North America (likely the United States, considering the author's heritage). Immediately, the reader is given the strong impression of a weary woman, aged beyond her physical years, and dealing with a difficult life and situation within the confines of her slaver's home and business.

The speaker of the poem is a hardworking woman and probably a single mother. Readers also know that she is poor because she mentions her hut, the manual labor that she is forced to do, and that nature is the only thing she owns. In the poem, nature is personified as a human being. For the speaker, nature is able to calm her. Besides, nature is also able to let her rest and rejuvenate her for the next day. Nature symbolizes her freedom and rejuvenation because it can help her recharge her soul and body to do her responsibility day by day, month by month, and year by year.

Another strong figure of speech in the poem is apostrophe. The speaker addresses some inanimate objects, that is, the elements of nature in order to strengthen her emotional state of tiredness. It seems that she speaks to the nature in order to relieve all the burdens, her stress and tiresome work she has to cope 
with. The two dominant figures of speech are used spontaneously when the speaker tries to speak to the nature.

The use of the poetic device known as personification is of special significance. The speaker endows the elements of nature (which are non-living objects) with human qualities in an attempt to feel less lonely. In the absence of human company, it is the sun, the rain, the snow, dewdrops, the wind, the sky, mountains, oceans, leaves, stones, "star shine" and "moon glow" that are her friends. Consider the second stanza below:

\section{Shine on me, sunshine \\ Rain on me, rain \\ Fall softly, dewdrops \\ And cool my brow again.}

The shortness of each line in the stanza stands in noticeable contrast to the lengthy and demanding list that constitutes the first stanza, and gives the second one a more calmed atmosphere. The second stanza is heavily laden with natural imageries. It invokes images of sun, rain, and dewdrops. The woman seems to be petitioning to the natural world, but she is not asking for anything more than for it to do what it is supposed to do. She is yearning for the world to deliver her phenomenon that is entirely natural. The speaker calls the elements of nature as she thinks that nature is her true companion. She addresses the sunshine to shine on her, the rain to rain on her, the dewdrops to fall softly on her, and cool her brow so that she may feel calmness in her own self.

Successively, the third stanza continues the speaker's yearning to the nature:

\section{Storm, blow me from here With your fiercest wind Let me float across the sky 'Til I can rest again.}

The third stanza follows a similar theme to the first one, with slightly rougher imagery. This time, the speaker invokes a "storm" that will take her away from where she is; to "float across the sky" and not to stop until she finds rest. In this stanza, it is rest she yearns for, a rest that is well-framed by the first stanza and its list of demanding and, in some cases, insulting things to do. In both stanzas, the word "again" concludes the thought. This is an important repetition that highlights nostalgic peace. She is remembering the last time she was able to rest, and the last time her brow was cool. When she thinks about this state of being, she recalls it as being natural, and yearns for it once again, associating it with imagery of the natural world, the world as it is supposed to be. By emphasizing nature, the speaker emphasizes the unnatural, another reference to her presumed slavery, or even to the fact that she has an enormous list of tasks for which it hardly seems that there are enough hours in the day. She really wants "storm" to blow her away from her tiresome work she has to do.

Additionally, the next stanza uses winter as a frame for discussing the idea of peace. Consider the fourth stanza below:

\section{Fall gently, snowflakes \\ Cover me with white \\ Cold icy kisses and \\ Let me rest tonight.}

The approach the speaker takes is to describe the wintry season as a quiet, peaceful time to convey the idea of a comfortable cold that allows her to feel restful. Word choice is crucial here - "gently," "snowflakes," "white," "kisses," and "rest," coupled with the perfect syllable and rhyming match on the second and fourth line, create an atmosphere of peace and rest. In the fourth stanza, once again she addresses another different nature, that is, "snowflakes" that visualizes the quiet white winter season that can bring her to the coldness of her soul after she goes home from wandering to her world of freedom.

Again, the speaker is yearning for a break from the life that is described in the first stanza and seems to never quite let up. The simple yearning for cool and white, for kisses of any kind, helps to create an image of this weary mother whose mind is filled with beautiful images, and whose life seems to deny them to her. The difficulties of motherhood and the pains of her predicament are made abundantly cleared through stanzas that do not discuss them at all, but rather focus on what her life makes her dream of instead. 
Furthermore, the natural imagery comes to a head in the final stanza of poem, consider the following:

$$
\begin{aligned}
& \text { Sun, rain, curving sky } \\
& \text { Mountain, oceans, leaf and stone } \\
& \text { Star shine, moon glow } \\
& \text { You're all that I can call my own. }
\end{aligned}
$$

The elements of nature are used to great effect, as the speaker considers that the only things in the world she can think of as belonging to her are the natural phenomena that surround her. This seems to confirm the theme of slavery suggested in the first stanza, that is, the speaker is, after all, a mother, and so surely she should consider her child to be something that belongs to her. It is incredibly peaceful imagery used to indicate such a powerful and revolting aspect of history, and serves to give that message a unique and memorable means of approaching the reader, and of staying with them each time the natural world does something wonderful. She speaks of "Sun", "rain", "curving sky", "mountain", "oceans", "leaf", and "stone". Her repetition of these outdoor scenarios come into great effect because out of all the things she may mention she mentions the freest, broadest places such as the ocean and mountain. She mentions areas where one can get lost and free; giving us an insight into her conscience.

The poetic devices that are used to beautify the poem are imagery, symbol, and two main figures of speech, that is, personification and apostrophes. The first stanza visualizes a picture of all the tasks the speaker must complete. In the second through fifth stanza, she uses seasonal examples which display a calming end to the speaker's day. While in stanzas two through five, personification and apostrophes are used. The speaker talks to nature as if it is a person. She addresses the elements of nature as the plead to give her just a moment of relaxation and escapism because of her tiring and boredom work she has done. She also claims that she owns nature which displays the deeper connection she has with the environment around her.

This poem shows the struggle of a woman who does not have a lot. It shows the struggle of having so much to take care of; and the struggle to maintain a home. Her lines such as "Star shine, moon glow you're all that I can call my own" show that she is a struggler. She does not have all the riches and nice things so she must resort to the nature surrounding her. This poem allows us to feel the amount of pressure and stress that is never recognized. Therefore, the speaker uses nature as her object of escapism because she understands that she is not able to go anywhere. The poem allows us into the mind of a dreamer and the outlet nature provides.

\section{Conclusion}

The poem looks at the idea of a woman demanding freedom from various chores that tie her down. Overburdened by work, the woman turns to nature for deliverance. This is indicated in the very last line of the poem where the narrator says, "You're all that I can call my own." In other words, the speaker seeks refuge in nature to escape the drudgery of her life.

"Woman Work" is a poem about a black working woman set in the southern states of the U.S. A. In the poem, the woman is very busy, as she lists all her chores in the first stanza. All this working makes her tired and she cries out to the elements to take her away from the frustration. The main theme in 'Woman Work' is work. We know this because of the long list of household jobs she's got to do in the first stanza. Another theme in the poem is loneliness. We can see this by the fact that she only mentions her children and not her partner/husband, if she has one. The message that the poet is trying to get through to the reader is that life can be horrible, and you have to do anything to survive.

The way that the poet has written this poem is on purpose. The first stanza makes the reader feel as though the woman is overworked because of the long list of chores. Note that the poet has not used any commas in the first stanza. This makes the pace intense and arouses a feeling of breathlessness and exhaustion in the reader. The lines being short and quick also add to this. We know that this woman is from the US because she uses a southern dialect: 'gotta', 'cane', 'cotton to pick', 
'chicken to fry'. This capture's the woman's voice, so it's as if she is talking to us.

The next four stanzas are four lined stanzas. This slows the pace right down. The purpose of this is so that it reflects what the woman is actually saying: 'Fall gently, snowflakes Cover me with white Cold icy kisses and Let me rest tonight.' The use of the comma is here to slow it down. 'Fall gently' is something that makes it feel more relaxed and calm. The four lined stanzas have a regular rhythm, which conveys comfort and security. The title 'Woman Work' is chosen because that is what the whole poem is about. The work that she is doing in the poem is for women only.

There are examples of figures of speech in the poem: "Storm, blow me from here With your fiercest wind" "Cover me with white Cold icy kisses... ." She wants the wind to blow her away from all the stress and work, and the snowflakes to cool her down with their 'kisses' and make her feel relaxed. The poet evokes a strong feeling of desperation in this poem: 'Storm, blow me from here' She is desperate because she calls upon the elements to whisk her away, which is not possible. The poet also creates a lonely atmosphere in the poem; "Sun, rain, curving sky... You're all that I can call my own." The things that she calls her own are not human. Thus she has nobody to talk to.

\section{References}

Annas, P. J. How the Poetry Works. Cambridge: Cambridge Publisher Ltd., 1996.

Baldick, C. The Concise Oxford Dictionary of Literary Terms. Oxford: Oxford University Press, 1990.

Barnet, S. An Introduction to Literature: Fiction/Poetry/Drama. Boston: Harper Collins Colle, 2005.

Cheuse, A \& Delbanco, N. Literature Craft and Voice. New York: Mc Graw-Hill, 2010.

D'haen, T. The Routledge Companion to World Literature. New York: Routledge, 2014.
George, M. W. The Element of Library Research: What Every Student Needs to Know. Princenton: Princeton University Press, 2008.

Greenblatt, Stephen. The Norton Anthology of English Literature Ed. 8, Vol. D. New York: Norton, 2006.

Guerin, W. L. A Handbook of Critical Approaches to Literature ( $5^{\text {th }}$ ed). New York: Oxford University Press, 2005.

Holman, C.H. \& Harmon, W. A Handbook to Literature $\left(10^{\text {th }}\right.$ ed). New York: Macmillan Publishing Company, 2006.

Kennedy X.J and Dana Gioia. Literature: An Introduction Fiction, Poetry, Drama and Writing. New York: Longman Publishing Ltd., 2010.

Kenney, William. How to Read and Write about Fiction. New York: Simon and Schuster, Inc., 2005.

Morris, R. The Language of Poetry. London: Longman, 2002.

Pratchett, Terry and Stephen Briggs. The Discworld Companion. New York: Amazon Publisher, 2002.

Punch, K. F. Developing Effective Research Proposals. London: SAGE Publications, 2000.

Rothenberg, David. Survival of the Beautiful: Art, Science and Evolution. London: Bloomsbury, 2011.

Popkin, Michael. Active Parenting: Teaching Cooperation, Courage, and Responsibility. San Francisco: Harper San Francisco, 2987.

Tan, Amy. The Bonesetter's Daughter. New York: G.P. Putnams, 2001. 